\title{
Experimental Investigation of the Performance and Emission Characteristics of a CI Engine Equipped with a Modified Truncated Cone Piston Crown Operated on Diesel and Shea-Butter Biodiesel
}

\author{
Olumide A. Towoju, Ademola A. Dare, and Samson K. Fashogbon
}

\begin{abstract}
Biodiesels and Improved combustion chamber design have better in-cylinder air motion which positioned them to offer increased advantages in addressing the major concern of high emission and low thermal efficiency of compression ignition engines. This study therefore investigated the impact of Shea-butter biodiesel and redesigned combustion chamber on the performance and emission characteristics of a compression ignition engine. Biodiesel was prepared from Shea-butter using the standard process. Experiments were conducted on a Yoshita-165F engine operated on a blend of AGO and Shea-butter biodiesel and then Yoshita-165F engine equipped with a truncated cone piston crown with a cone baseangle of $40^{\circ}$ modified from the standard piston, operated on a blend of AGO and Shea-butter to determine the engines' performance characteristics using a TQ TD115 MKH Absorption Dynamometer. The performance and emission characteristic of the engine witnessed an improvement with the use of the truncated cone piston crown with a cone base-angle of $40^{\circ}$. This was also observed with AGO/Shea-butter biodiesel blend as fuel and was particularly well pronounced when utilized as a fuel for the truncated cone piston crown equipped engine. Compression ignition engine equipped with the modified piston and operated on AGO/Shea-butter biodiesel led to improvement in performance.
\end{abstract}

Index Terms-Combustion Chamber; Truncated Cone Piston Crown; Shea-Butter Biodiesel.

\section{INTRODUCTION}

Asides the dwindling reserves of crude oil, the effect of climate change is now being felt more than ever before necessitating the renewed call for reduced or if possible zero emissions from energy generation devices which relies on the combustion of fuels. Some of the methods adopted to address the aforementioned challenges are the use of biodiesels in compression ignition engines, and the redesigning of its combustion chamber.

The performance and emission characteristic of a compression ignition engine is also largely dependent on the air-turbulence inside its combustion chamber as this dictates the in-cylinder motion. The combustion chamber geometry is thus a major determinant of the combustion temperature and air-fuel mixing. This determines the products of combustion and the amount of energy that can be extracted from the fuel.

Published on October 312018.

O. A. Towoju (Corresponding Author) is with Adeleke University, Ede, Nigeria (e-mail: olumidetowo@yahoo.com).

A. A. Dare and S. K. Fashogbon are with University of Ibadan, Nigeria.
Biodiesels are derived from various vegetable oils and animal fats and can be used in compression ignition engines for the energy generation. The challenge which would have resulted from the need to derived biodiesels from edible plants as against using the plants in meeting the food requirements of the populace have encouraged the production of biodiesels from non-edible plants.

Vegetable oil in its raw form is not made use of in fueling compression ignition engines mainly because of its high viscosity which leads to poor fuel atomization, fuel injector coking and piston ring sticking which results into reduced engine life, it is therefore refined to produce biodiesels through the widely accepted method of transesterification.

Biodiesels have been proven by the results of numerous studies to have similar properties to automotive gas oil (AGO), and its impact on the performance and emission characteristics of compression ignition engines have made it be the preferred choice as an alternative to AGO.

The biodiesel utilized in this study was produced from Shea-butter. Shea-butter is available in abundance in Nigeria, and in most cases is used as a skin moisturizer in the south-western part of the country.

This study seeks to determine the effect of combustion chamber redesign of a compression ignition engine operated on biodiesel.

Different shapes/geometries of the combustion chamber have been worked upon by many scholars, and it has been established that the performance characteristic of a compression ignition engine is dependent on shape of its combustion chamber [1]-[9].

Numerical studies on the use of a truncated cone piston crown equipped compression ignition engine showed an improvement in performance and emission characteristics, and were particularly well pronounced at a cone base angle of $40^{\circ}$ [1].

The toroidal combustion chamber shape from different studies have shown the best improvement in performance characteristics especially for brake thermal efficiency, brake power, carbon-monoxide (CO) emission, hydrocarbons (HC) emission and smoke density, however it came with a cost in terms of (nitrogen oxides) NOx emission increment [2],[5],[9]-[11]. The use of toroidal re-entrant combustion chamber offers even better air momentum in the combustion chamber and leads to better improvement in engine performance than the toroidal combustion chamber [9]. The re-entrant bowl combustion chamber shape favours low NOx emission [12] while the spherical combustion chamber 
shape leads to a reduction in the emission of $\mathrm{CO}$ and $\mathrm{HC}$ [2],[10].

The most important controlling factor of the combustion process in compression ignition engine is the in-cylinder fluid motion. [13],[14] Combustion chamber shape redesign that results into better in-cylinder motion leads to an improvement in the performance characteristics of a compression ignition engine [5],[8], even as it is obtained in the toroidal combustion chamber geometry, multichambered piston crown and piston crown with grooves which results in better utilization of oxygen for combustion [2],[7],[11],[13].

The growing concern about the cost of AGO and its attendant release of toxic emission on combustion has continued to push interest in the use of biodiesel as an alternative fuel in compression ignition engines. Biodiesels are produced from the process of transesterification of vegetable oils to reduce its high viscosity [15]. Blends of AGO/biodiesel of different ratios have been experimented upon giving favourable results especially in the reduction of emission of some toxic waste (CO and $\mathrm{HC}$ ) in most cases [16]-[21].

Blends of $\mathrm{AGO} /$ biodiesel at high compression ratios can have higher brake thermal efficiency value than that generated with the use of AGO. [16] Carbon-monoxide emission from compression ignition engines operated on biodiesel/AGO blends in some instances can be 70\% [22], and smoke levels can be $65 \%$ lower [23] than the emission released by operating the engine on AGO. The emission of un-burnt hydrocarbons, $\mathrm{CO}$ and particulate matters are usually generally reduced with the use of biodiesels [21]. The use of appropriate biodiesel blends in compression ignition engines has also been proven to have a positive impact on its brake thermal efficiency [17]. Utilizing biodiesel/AGO blends in compression ignition engines can also help in the reduction of soot emission [19], and at optimum blend ratio, the engine can generate more power, lower brake specific fuel consumption values [18] and even an improved thermal efficiency [24]. Increased fraction of Ethanol in blend with biodiesel results into improved thermal efficiency and reduced $\mathrm{CO}$ and $\mathrm{CO}_{2}$ emissions [20].

However, the use of biodiesels as an alternative to AGO in powering of compression ignition engines leads to an increment in the emission of NOx [16]-[22].

\section{MATERIALS AND METHODS}

A horizontal single cylinder four-stroke air-cooled compression ignition engine; Yoshita-165F model, dynamometer type TQ TD115 MKH Absorption Dynamometer, exhaust gas analyzer, vibrometer, and a stopwatch were used in the course of this study. The engine and dynamometer details are depicted in Table I and II below respectively.

\begin{tabular}{ll}
\hline Rated Speed (RPM) & 2600 \\
Rated Power "P" (kW) & 2.67 \\
Compression Ratio "CR" & $20.5: 1$ \\
Cylinder bore "D" (m) & 0.070 \\
Stroke "S" (m) & 0.070 \\
\hline \hline & \\
\multicolumn{2}{l}{ TABLE II: TQ TD115 MKH ABSORPTION DYNAMOMETER SPECIFICATION } \\
\hline \hline Parameters & Value \\
\hline Power Range (kW) & 2.5 - 7.5 \\
Torque (Nm) & 15 (maximum) \\
Speed (RPM) & 6000 (maximum) \\
\hline \hline
\end{tabular}

The performance characteristic of the engine was determined using AGO, AGO/Shea-butter blend, and Sheabutter biodiesel as fuel.

\section{A. Shea-butter Biodiesel Preparation}

The biodiesel was prepared from Shea-butter which was sourced locally from Ogbomoso town in Nigeria and ethanol using the standard technique of transesterification and taking the necessary precautions into consideration. The produced Shea-butter biodiesel and a prepared blend of 50:50 AGO/Shea-butter biodiesel were stored in well-covered glass bottles.

\section{B. Physicochemical Properties of Test Fuels}

The physical and chemical properties of the utilized fuel were determined using a standard testing technique for density, specific gravity, kinematic viscosity, pour point, flash point, fire point, cloud point, $\mathrm{pH}$ value, ash content, cetane number and calorific value.

\section{Combustion Chamber Modification}

The engine's piston crown was modified to a truncated cone with a cone base-angle of $40^{\circ}$ and a tapered height of $0.005 \mathrm{~m}$. To ensure that the equipped with the truncated cone piston crown has the same compression ratio as that of the standard engine, the piston crown was filled with the calculated volume of material to be removed for the modification.

The volume of the removed material was calculated using the relation:

$$
V=\pi r^{2} H_{0}-\left(\frac{\pi r^{2} H}{3}-\frac{\pi\left(r-r_{0}\right)^{2}\left(H-H_{0}\right)}{3}\right)
$$

Where $\mathrm{H}_{0}=0.005 \mathrm{~m}, \mathrm{r}=\mathrm{D} / 2=0.035 \mathrm{~m}$, and $\theta=40^{\circ}$

$$
\begin{aligned}
& H=\frac{r}{\tan \theta} \\
& H=\frac{0.035}{\tan 40^{\circ}}=0.0417 \mathrm{~m} \\
& \mathrm{r}_{0}=\mathrm{H}_{0} \tan \theta=0.005 * \tan 40^{\circ}=0.0042 \mathrm{~m} \\
& V_{r}=\pi * 0.035^{2} * 0.005-\left(\frac{\pi * 0.035^{2} * 0.0417}{3}-\right. \\
& \left.\frac{\pi}{3}(0.035-0.0042)^{2}(0.0417-0.005)\right) \quad=2.2073 * 10^{-6} \mathrm{~m}^{3}
\end{aligned}
$$

A sketch of this is shown below in Fig. 1

Parameters Specification




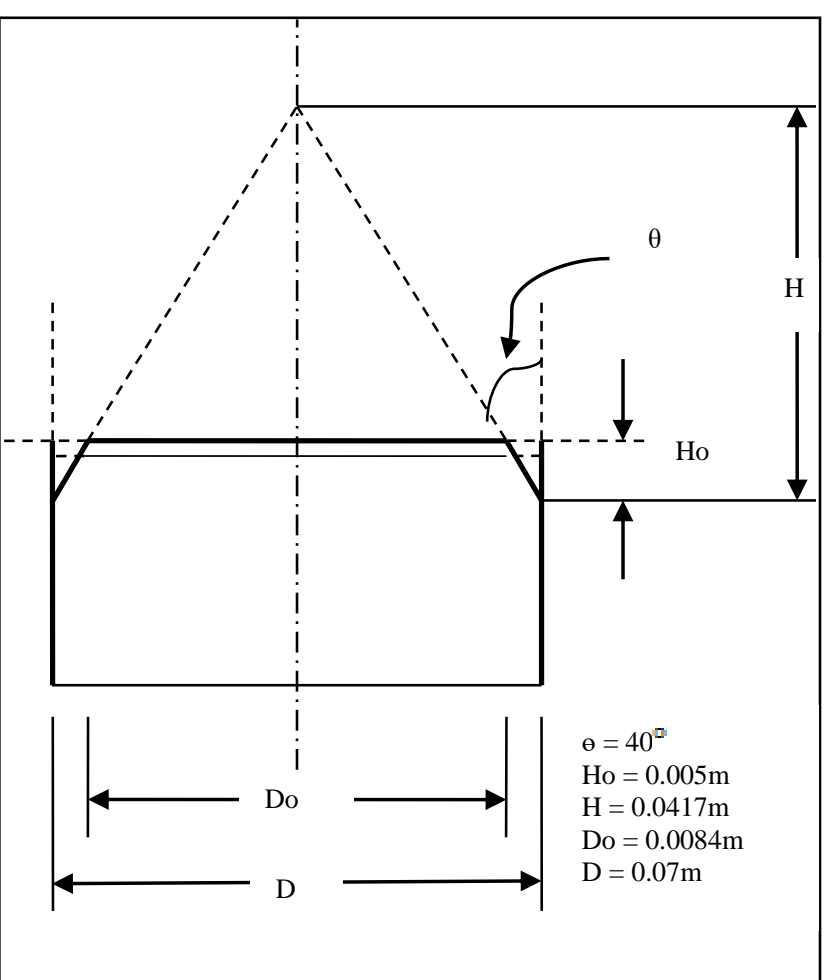

Fig. 1. Truncated cone piston crown modification

The engine piston material was made from aluminium and this same material was utilized in the modification process. Fig. 2 below depicts the modified piston crown.

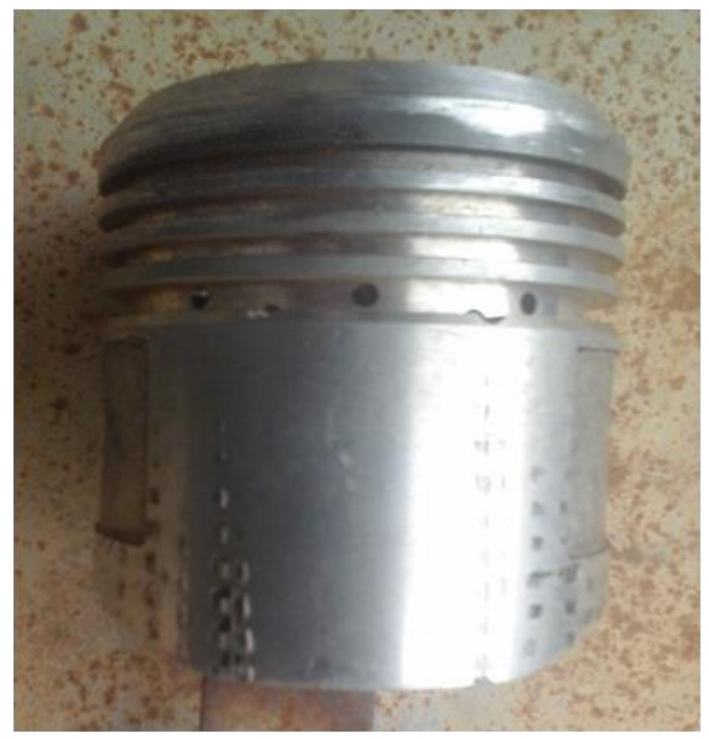

Fig. 2. Truncated cone piston

\section{Experimental Procedure}

The schematic of the experimental set-up is depicted in Fig. 3.

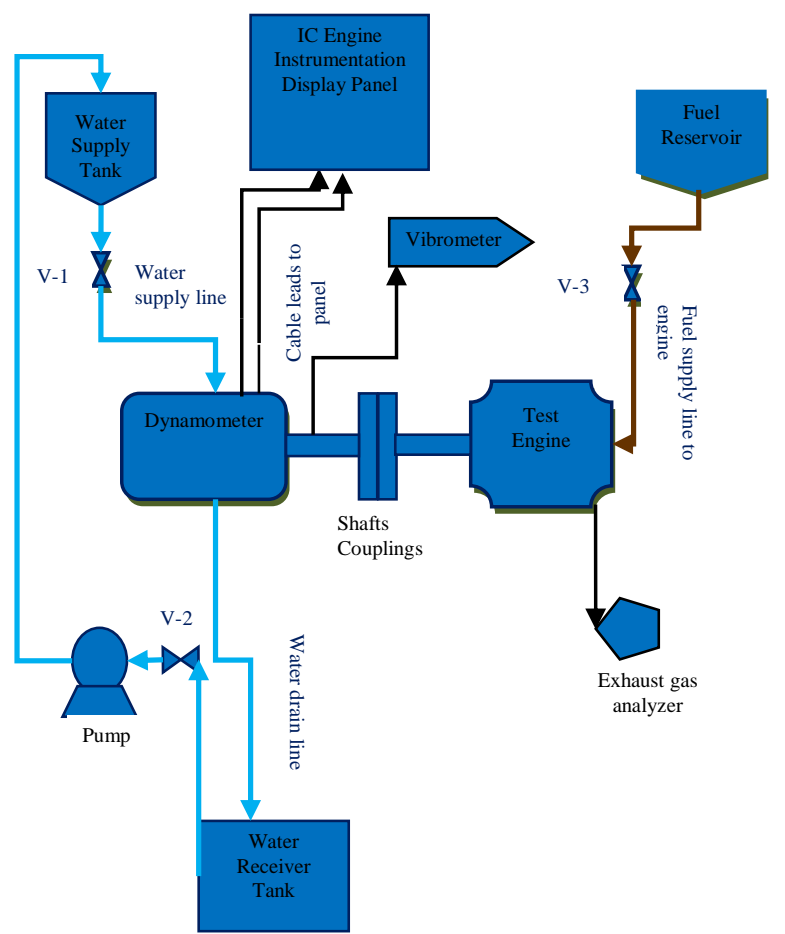

Fig. 3. Experimental set-up schematics

Fig. 4 is a pictorial view of the experimental rig depicting the test engine, dynamometer, vibrometer, instrumentation panel, water pump, and water receiver tank.

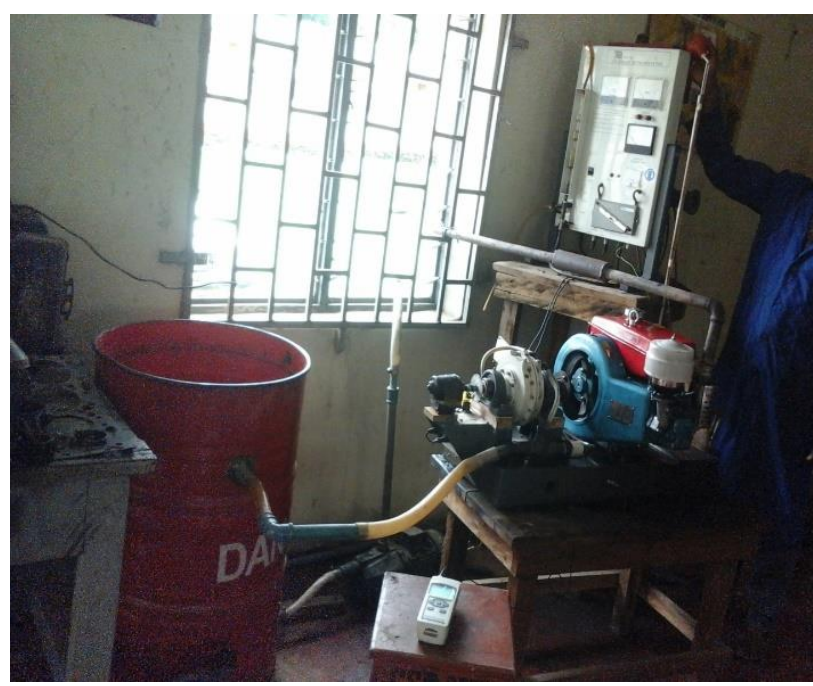

Fig. 4. Experimental rig

The experiment was carried out using the standard equipped piston and run with AGO (B0), AGO/Shea-butter biodiesel blend in the ratio 50:50 (B50), and Shea-butter biodiesel (B100) respectively. The fuel flow rate was determined with the use of a stopwatch; the average time it took the engine to combust $2 \mathrm{ml}$ of fuel was measured and this was used to compute the fuel flow rate. Readings of engine torque, speed, exhaust gas temperature, vibration, and $\mathrm{CO}$ emission levels were taken appropriately for the respective fuels.

The experiment was then later carried out on the engine but this time equipped with the truncated cone piston crown with a cone base-angle of $40^{\circ}$ and also run on B0, B50, and $\mathrm{B} 100$ respectively, and the readings of interest were taken just as it was done for the standard piston equipped engine. 
The engine performance characteristics of interest namely; brake power (BP), thermal efficiency $\left(\eta_{T h}\right)$, mechanical efficiency $\left(\eta_{M}\right)$, and brake specific fuel consumption (BSFC) were then deduced using these relations.

$$
\begin{aligned}
& B P=\frac{2 \pi N T_{q}}{60} \\
& \eta_{T h}=\frac{B P}{F C * C V}
\end{aligned}
$$

$\mathrm{BP}$ is the net power of the engine

$\mathrm{T}_{\mathrm{q}}$ is the engine torque

$\mathrm{N}$ is the engine speed in RPM

$\mathrm{FC}$ is the fuel consumption rate $(\mathrm{kg} / \mathrm{s})$

$\mathrm{CV}$ is the calorific value of a kilogram of fuel

While the mechanical efficiency is calculated using the relation:

$$
\eta_{M}=\frac{\text { Brake power }}{\text { Indicated power }}
$$

The brake specific fuel consumption is determined using the relation:

$$
B S F C=\frac{\rho f q}{B P}
$$

$\rho_{f}$ is the density of the fuel

$q$ is the fuel consumption rate, and is determined using the relation;

$$
q=\frac{0.000002}{t}
$$

\section{RESULTS}

The physicochemical properties of the test fuels are depicted in Table III.

TABLE III: PHYSICOCHEMICAL PROPERTIES OF THE TEST FUELS

\begin{tabular}{llll}
\hline \hline Properties & B0 & B50 & B100 \\
\hline Density $(\mathrm{g} / \mathrm{ml})$ & 0.84 & 0.854 & 0.92 \\
Specific gravity & 0.84 & 0.86 & 0.923 \\
Kinematic viscosity at $30^{\circ} \mathrm{Cmm}^{2} / \mathrm{s}$ & 3.7 & 4.1 & 5.4 \\
Pour Point ${ }^{\circ} \mathrm{C}$ & -35 & +7.6 & +18 \\
Flash Point ${ }^{\circ} \mathrm{C}$ & +114 & +126 & +191 \\
Fire Point ${ }^{\circ} \mathrm{C}$ & +132 & +133 & +212 \\
Cloud Point ${ }^{\circ} \mathrm{C}$ & -28 & +13 & +32 \\
PH Value & 8.10 & 5.5 & 4.5 \\
Ash content & 0.05 & 0.13 & 0.21 \\
Cetane Number & 39.6 & 42.6 & 44.8 \\
Calorific Value $(\mathrm{MJ} / \mathrm{kg})$ & 36 & 38.7 & 40.1 \\
\hline \hline
\end{tabular}

The measured values of the exhaust gas temperature of the engine when equipped with its standard piston and with truncated cone piston crown respectively for the respective test fuels is depicted in Table IV.

The measured values of the engine speed when equipped with its standard piston and with truncated cone piston crown respectively for the respective test fuels is depicted in Table V.

Table VI gives the value of the engine vibration when fitted with the unmodified piston and the truncated cone

\begin{tabular}{|c|c|c|c|}
\hline \multicolumn{4}{|c|}{ TABLE VI: ENGINE VIBRATIONS } \\
\hline Piston Crown Type & $\begin{array}{l}\mathrm{B} 0 \\
\left(\mathrm{~m} / \mathrm{s}^{2}\right)\end{array}$ & $\begin{array}{l}\mathrm{B} 50 \\
\left(\mathrm{~m} / \mathrm{s}^{2}\right)\end{array}$ & $\begin{array}{l}\mathrm{B} 100 \\
\left(\mathrm{~m} / \mathrm{s}^{2}\right)\end{array}$ \\
\hline $\begin{array}{l}\text { Unmodified Piston Crown } \\
\text { fitted Engine }\end{array}$ & 19.4 & 17.6 & 12.8 \\
\hline $\begin{array}{l}\text { Truncated Cone Piston } \\
\text { Crown equipped Engine }\end{array}$ & 25.8 & 42.1 & 39.2 \\
\hline
\end{tabular}
piston crown respectively for the respective test fuels.
TABLE IV: EXHAUST GAS TEMPERATURE OF THE TEST ENGINE

\begin{tabular}{llll}
\hline \hline Piston Crown Type & B0 $(\mathrm{K})$ & $\mathrm{B} 50(\mathrm{~K})$ & $\mathrm{B} 100(\mathrm{~K})$ \\
\hline $\begin{array}{l}\text { Unmodified Piston Crown fitted } \\
\begin{array}{l}\text { Engine } \\
\text { Truncated Cone Piston Crown } \\
\text { equipped Engine }\end{array}\end{array}$ & 683 & 618 & 643 \\
\hline \hline
\end{tabular}

\begin{tabular}{llll}
\multicolumn{4}{c}{ TABLE V: ENGINE SPEED } \\
\hline \hline Piston Crown Type & $\begin{array}{l}\text { B0 } \\
\text { (RPM) }\end{array}$ & $\begin{array}{l}\text { B50 } \\
(\mathrm{RPM})\end{array}$ & $\begin{array}{l}\text { B100 } \\
(\mathrm{RPM})\end{array}$ \\
\hline $\begin{array}{l}\text { Unmodified Piston Crown fitted } \\
\begin{array}{l}\text { Engine } \\
\text { Truncated Cone Piston Crown } \\
\text { equipped Engine }\end{array}\end{array}$ & 1900 & 1900 & 2000 \\
\hline \hline
\end{tabular}

Table VII gives the calculated value of brake power of the engine using (3) when fitted with the unmodified piston and the truncated cone piston crown respectively for the respective test fuels.

The calculated thermal efficiency values of the engine using (4) when equipped with its standard piston and with truncated cone piston crown respectively for the respective test fuels is depicted in Table VIII below.

Table IX gives the calculated value of engine mechanical efficiency using (5) when fitted with the unmodified piston and the truncated cone piston crown respectively for the respective test fuels.

Table $\mathrm{X}$ gives the calculated value of engine mechanical efficiency using (6) when fitted with the unmodified piston and the truncated cone piston crown respectively for the respective test fuels.

TABLE VII: BRAKE POWER OF TEST ENGINE

\begin{tabular}{llll}
\hline \hline Piston Crown Type & $\begin{array}{l}\text { B0 } \\
\text { Brake } \\
\text { Power (W) }\end{array}$ & $\begin{array}{l}\text { B50 } \\
\text { Brake } \\
\text { Power (W) }\end{array}$ & $\begin{array}{l}\text { B100 } \\
\text { Brake } \\
\text { Power (W) }\end{array}$ \\
\hline $\begin{array}{l}\text { Unmodified Piston Crown } \\
\text { fitted Engine }\end{array}$ & 1790.71 & 1750.91 & 1844.96 \\
$\begin{array}{l}\text { Truncated Cone Piston } \\
\text { Crown equipped Engine }\end{array}$ & 1796.99 & 1806.42 & 1926.84 \\
\hline \hline
\end{tabular}

TABLE VIII: THERMAL EFFICIENCY OF TEST ENGINE

\begin{tabular}{llll}
\hline \hline Piston Crown Type & $\begin{array}{l}\mathrm{B} 0 \\
\boldsymbol{\eta}_{\boldsymbol{h}}(\%)\end{array}$ & $\begin{array}{l}\mathrm{B} 50 \\
\boldsymbol{\eta}_{\boldsymbol{\tau} \boldsymbol{h}}(\%)\end{array}$ & $\begin{array}{l}\mathrm{B} 100 \\
\boldsymbol{\eta}_{\boldsymbol{\tau} \boldsymbol{h}}(\%)\end{array}$ \\
\hline $\begin{array}{l}\text { Unmodified Piston Crown } \\
\text { fitted Engine }\end{array}$ & 13.74 & 20.65 & 16.05 \\
$\begin{array}{l}\text { Truncated Cone Piston } \\
\text { Crown equipped Engine }\end{array}$ & 12.60 & 26.67 & 25.08 \\
\hline \hline
\end{tabular}

\begin{tabular}{llll}
\multicolumn{4}{c}{ TABLE IX: MECHANICAL EFFICIENCY } \\
\hline \hline & $\mathrm{B} 0$ & $\mathrm{~B} 50$ & $\mathrm{~B} 100$ \\
Piston Crown Type & $\eta_{M}$ & $\eta_{M}$ & $\eta_{M}$ \\
& $(\%)$ & $(\%)$ & $(\%)$ \\
\hline Unmodified Piston Crown fitted Engine & 67.07 & 65.58 & 69.10 \\
$\begin{array}{l}\text { Truncated Cone Piston Crown equipped } \\
\text { Engine }\end{array}$ & 67.30 & 67.66 & 72.13 \\
\hline
\end{tabular}


TABLE X: BRAKE SPECIFIC FUEL CONSUMPTION OF THE TEST ENGINE

\begin{tabular}{|c|c|c|c|}
\hline & B0 & B50 & B100 \\
\hline Piston Crown Type & $\begin{array}{l}\text { BSFC } \\
(\mathrm{kg} / \mathrm{kWh}) \\
\rho_{f}=840 \\
\mathrm{~kg} / \mathrm{m}^{3}\end{array}$ & $\begin{array}{l}\text { BSFC } \\
(\mathrm{kg} / \mathrm{kWh}) \\
\rho_{f}=854 \\
\mathrm{~kg} / \mathrm{m}^{3}\end{array}$ & $\begin{array}{l}\text { BSFC } \\
(\mathrm{kg} / \mathrm{kWh}) \\
\rho_{f}=920 \\
\mathrm{~kg} / \mathrm{m}^{3}\end{array}$ \\
\hline $\begin{array}{l}\text { Unmodified Piston } \\
\text { Crown fitted Engine }\end{array}$ & 0.7278 & 0.450 & 0.5992 \\
\hline $\begin{array}{l}\text { Truncated Cone Piston } \\
\text { Crown equipped Engine }\end{array}$ & 0.7936 & 0.3487 & 0.3294 \\
\hline
\end{tabular}

The measured value of the $\mathrm{CO}$ emissions when the engine is equipped with its standard piston and with truncated cone piston crown respectively for the respective test fuels is depicted in Table XI.

TABLE XI: CO EMISSIONS

\begin{tabular}{llll}
\hline \hline Piston Crown Type & $\begin{array}{l}\text { B0 } \\
(\mathrm{ppm})\end{array}$ & $\begin{array}{l}\mathrm{B} 50 \\
(\mathrm{ppm})\end{array}$ & $\begin{array}{l}\mathrm{B} 100 \\
(\mathrm{ppm})\end{array}$ \\
\hline $\begin{array}{l}\text { Unmodified Piston Crown fitted Engine } \\
\text { Truncated Cone Piston Crown equipped }\end{array}$ & 1598 & 1870 & 1859 \\
\begin{tabular}{l} 
Engine \\
\hline
\end{tabular} & 1463 & 1115 & 780 \\
\hline
\end{tabular}

The exhaust gas temperature of the truncated cone piston crown equipped engine was for all the respective fuels lesser than that of the standard piston equipped engine given an indication of a better utilization of the fuel's energy and an expected reduced emission. The exhaust gas temperature value decreases with the increase in the amount of biodiesel for the truncated cone piston crown equipped engine and this is in agreement with earlier findings [16], [25].

The engine vibration at full load reduced with the increase in the amount of Shea-butter biodiesel for the unmodified piston equipped engine, this could be attributed to better lubrication as a result of the increased viscosity. However, with the truncated cone piston crown fitted engine, the vibration levels increased for the three utilized test fuels and this can be attributed to the change in the combustion chamber design without a corresponding redesign of the other parts and components of the engine.

The brake power of the truncated cone piston crown equipped engine was for the respective fuel type greater than that equipped with the unmodified piston giving an indication that the combustion chamber redesign encourages better in-cylinder air motion [1],[26]. The Shea-butter biodiesel fuelled engine also gave an increased brake power value than AGO because of its higher calorific value as evidenced in Table III; this similar trend was followed by the mechanical efficiency of the engine when equipped with the unmodified piston and the truncated cone piston crown and run on B0, B50, and B100 respectively.

The thermal efficiency of the engine was highest when it was operated on B50 as fuel when equipped with the standard/unmodified piston and with the truncated cone piston crown respectively. The thermal efficiency of a biodiesel fuelled compression ignition engine higher than that run with AGO has a place in the literature [27]. The highest percentage increment in thermal efficiency value was recorded with the use of B100 as fuel in the truncated cone piston crown equipped engine over that of the unmodified piston, this may be attributed to its higher calorific value giving room for better utilization with improved combustion condition.
The brake specific fuel consumption for the engine improved with the use of the truncated cone piston crown except when operated on B0, and this is not unconnected with the improve in-cylinder air motion resulting into better mixing created by the combustion chamber redesign. It is lower with the use of Shea-butter biodiesel as fuel, although it did not follow a definite pattern for the unmodified piston equipped engine. The improvement in the BSFC with the use of Shea-butter biodiesel cannot but be connected with its higher calorific value.

Carbon-monoxide emission levels reduced with the use of the truncated cone piston crown due to better combustion leading to a near-complete combustion process. For the truncated cone piston crown equipped engine, the $\mathrm{CO}$ emission was also found to decrease with the increase in the percentage of Shea-butter biodiesel; this was as a result of increased oxygen level available for the combustion process.

\section{CONCLUSION}

- The redesign and modification of Yoshita-165F combustion chamber accomplished by the use of the truncated cone piston crown with a cone base-angle of $40^{\circ}$ led to an improvement in the performance and emission characteristics of the engine.

- The engine brake power, thermal efficiency, mechanical efficiency, brake specific fuel consumption, and carbon-monoxide emission showed an improvement when the engine was equipped with the truncated cone piston over the standard piston equipped engine using B50 and B100 as fuel.

- The use of Shea-butter biodiesel led to the improvement of the engine performance and emission characteristics, especially for the truncated cone piston crown equipped engine.

The engine vibration increased with the use of the truncated cone piston crown.

\section{REFERENCES}

[1] O. A. Towoju, \& A. A. Dare, "Impact of Conical Piston Crown Equipped Compression Ignition Engine on Performance", European Journal of Engineering and Technology, vol. 6 (1), 13-25, 2018.

[2] V. R. Mamilla, M. Mallikarjun, \& G. N. Rao. "Effect of Combustion Chamber Design on a DI Diesel Engine Fuelled with Jatropha Methyl Esters Blends with Diesel", International Conference On DESIGN AND MANUFACTURING, IConDM 2013, 479-490, 2013. India: Elsevier Ltd.

[3] A. Indrodia, N. Chotai, \& B. Ramani. "Investigation of Different Combustion Chamber Geometry on Diesel Engine using CFD Modelling of In-cylinder Flow for Improving the Performance of Engine", 5th International \& 26th All India Manufacturing Technology, Design and Research Conference (AIMTDR 2014), 4891 - 489-6, 2014. Assam.

[4] A. De Risi, \& D. F. Manieri. "A Theoretical Investigation on the Effects of Combustion Chamber Geometry and Engine Speed on Soot and NOx Emissions", Proceedings of ASME 1999 fall technical conference, ICE-vol. 33/1; 1999, 1-10, 1999. ASME.

[5] R. Banapurmath, B. Dodamani, S. Khanda, S. Hiremath, \& V. Math "Performance, Emission Characteristics of Dual Fuel (DF) \& Homogeneous Charge Compression Ignition (HCCI) Engines Operated on Compressed Natural Gas (CNG)" Uppage Oil Methylester (UOME), Universal Journal of Renewable Energy, vol. 2, 32-44, 2015.

[6] S. Jafarmadar \& M. Khanbabazadeh. "A Computational Study of the Effects of Combustion Chamber Geometries on Combustion Process 
and Emission in a DI Diesel Engine", Journal of Fuel and Combustion, vol. 1 (1), 1-16, 2008.

[7] C. R. Rajashekhar, T. K. Chandrashekar, C. Umashankar \& R. H. Kumar. "Studies on Effects of Combustion Chamber Geometry and Injection Pressure on Biodiesel Combustion", Transactions of the Canadian Society for Mechanical Engineers, 429-438, 2012.

[8] C. S. Reddy, C. E. Reddy, \& K. H. Reddy. "Effect of Tangential Grooves on Piston Crown of D.I. Diesel Engine with Blends of Cotton Seed Oil Methyl Easter", IJRRAS, vol. 13 (1), 150-159, 2012.

[9] P. S. Varun, S. K. Tiwari, R. Singh, \& N. Kumar. "Modification in combustion chamber geometry of CI engines for suitability of biodiesel: A review", Renewable and Sustainable Energy Reviews, vol. 79, 1016-1033, 2017.

[10] S.L. Ranganatha, T. Chandrashekar, N. Banapurmath, \& P. Nashipudi. "Effect of Injection Timing, Combustion Chamber Shapes and Nozzle Geometry on the Diesel Engine Performance", Universal Journal of Petroleum Sciences, vol. 2, 74-95, 2014.

[11] S. Jaichandar, \& K. Annamalai. "Effects of open combustion chamber geometries on the performance of pongamia biodiesel in a DI diesel engine", Fuel, vol. 98, 272-279, 2012.

[12] A. Lofti \& H. Ghassemi. "A Review on the Different Geometries of Combustion Chamber in CI Engines on Performance, Ignition and Emission", Journal of Atmospheric Pollution, 5 (2), 40-46, 2017.

[13] V. V. Bharathi \& G. Prasanthi. "The Influence of Air Swirl on Combustion and Emissions in a Diesel Engine", International Journal of Researh in Mechanical Engineering and Technology, vol. 3 (2), 14 16, 2013.

[14] J. B. Heywood. Internal Combustion Engine Fundamentals. New York: MCGrawHill, 1998

[15] B. K. Barnwal \& M. P. Sharma. "Prospects of biodiesel production from vegetable oils in India", Renew Sustain Energy Rev. vol 9(4):363-378, 2005.

[16] K. Naveen, T. P. Parameshwaran, \& P. Azhagiri. "Experimental Investigation of Variable Compression Ratio Diesel Engine using Ziziphus Jujuba oil”, 2014 International Conference on Innovations in Engineering and Technology (ICIET'14). III, 1134-1139, 2014. Madurai, Tamil Nadu: International Journal of Innovative Research in Science, Engineering and Technology.

[17] M. Anandan, S. Sampath, \& N. M. Sudharsan. "Effect of Compression Ratio and Exhaust Gas Recirculation (EGR) on Combustion, Emission and Performance of DI Diesel Engine with
Biodiesel Blends", Global Journal of Researches in Engineering: A Mechanical and Mechanics Engineering, vol. 14 (7), 1-16, 2014

[18] W. M. Adaileh, \& K. S. AlQdah. "Performance of Diesel Engine Fuelled by a Biodiesel Extracted from a Waste Cooking Oil”, Energy Procedia, vol. 18, 1317-1334, 2012.

[19] B. Kathirvelu \& S. Subramanian. "Performance and emission characteristics of biodiesel blends in a premixed compression ignition engine with exhaust gas recirculation", Environmental Engineering Research, vol. 22 (3), 294-301, 2017.

[20] W. Tutak, A. Jamrozik, A., \& M. Pyrc. "Experimental investigations on combustion, performance and emissions characteristics of compression ignition engine powered by B100/ethanol blend", Energy and Fuels, 1-10, 2016

[21] J. Xue, T. E. Grift, \& A. C. Hansena. "Effect of biodiesel on engine performances and emissions" Renewable and Sustainable Energy Reviews, vol. 15, 1098-1116, 2011.

[22] M. Ozkan. "Comparative Study of the Effect of Biodiesel and Diesel Fuel on a Compression Ignition Engine's Performance, Emissions, and Its Cycle by Cycle Variations", Energy Fuels, vol. 21(6), 3627 3636, 2007

[23] M. Canakci \& J. H. Van Gerpen. "Comparison of Engine Performance and Emissions for Petroleum Diesel Fuel, Yellow Grease Biodiesel, and Soybean Oil Biodiesel", ASAE Annual international meeting, vol. 46(4), 937-944, 2001.

[24] M. N. Nasim, R. B. Yarasu, R. B., \& Sarda, R. H. "Experimental investigation on compression ignition engine powered by preheated neat jatropha oil", Journal of Petroleum Technology and Alternative Fuels, vol. 4(7), 119-124, 2013.

[25] A. Anbarasu \& A. Karthikeyan. "Performance and Emission Characteristics of Direct Injection Diesel Engine Running On Canola Oil / Diesel Fuel Blend", American Journal of Engineering Research (AJER), vol. 3(8), 202-207, 2014.

[26] O. A. Towoju \& A. A. Dare. "Frustum Cone Piston Crown Equipped Compression Ignition Engine Performance Characteristics", American Journal of Engineering Research (AJER), vol. 7(3), 317-330, 2018.

[27] Y. Jehad, S. Nina, \& M. Hamdan. "Performance of CI engines using Biodiesel as fuel", GCREEDER international conference, 1-13, 2009. Amman: GCREEDER 